\title{
Can multinational companies foster institutional change and sustainable development in emerging countries? A case study
}

\author{
Francisco Javier Forcadell ${ }^{1,2}$ (D) | Elisa Aracil ${ }^{3,4}$ (D)
}

\author{
${ }^{1}$ Researcher, ESIC Business and Marketing \\ School, Madrid, Spain \\ ${ }^{2}$ Department of Management, Universidad \\ Rey Juan Carlos, Madrid, Spain \\ ${ }^{3}$ Universidad Pontificia Comillas-Icade, \\ Madrid, Spain \\ ${ }^{4}$ Universidad Francisco de Vitoria, Madrid, \\ Spain \\ Correspondence \\ Elisa Aracil, Universidad Pontificia Comillas- \\ Icade, Madrid, Spain. \\ Email: earacil@comillas.edu \\ Funding information \\ Spanish Ministry of Economy and Competi- \\ tiveness, Grant/Award Numbers: ECO2016- \\ 75379-R and ECO2015-67434-R; Fundación \\ Hergar, Madrid
}

\begin{abstract}
Emerging countries present institutional necessities that hinder their sustainable development. In the face of this challenge, companies, and in particular multinational companies (MNCs), can foster sustainable development through their corporate social responsibility (CSR) initiatives. This study focuses on the role of institutional change in transforming CSR into sustainable development in emerging countries. To this end, we propose a view of CSR focused on its institutional determinants and outcomes from a social and developmental perspective. By using quantitative and qualitative data, we analyse the case of three MNCs from different industries based in Europe and operating in Mexico. The case study shows how firms can stimulate institutional change in developing economies and contribute to their sustainable development as measured by the sustainable development goals. Various mechanisms about how this process is made are devised: institutional entrepreneurship, multistakeholder initiatives, interconnection of different institutional dimensions, and subsidiary entrepreneurship. The case study highlights the interaction among MNCs, developing countries, and institutions and how firms' sustainable actions scale up to the macro level.
\end{abstract}

\section{KEYWORDS}

corporate social responsibility, institutional change, institutional necessities, Latin America, Mexico, sustainable development, sustainable development goals

\section{I INTRODUCTION}

Long-run economic growth relies on developed institutions (Casson, Della Giusta, \& Kambhampati, 2010). However, emerging countries are often distinguished by their weak institutions. Against this shortage, companies, and particularly multinational companies (MNCs), have the potential to play a key role in boosting the progress of developing economies (Meyer, 2004) through their corporate social responsibility (CSR) activities. Nevertheless, extant literature has focused on the internal-to-the-firm CSR outcomes, disregarding the firm's external consequences such as its contribution to economic development in the emerging host country. In this context, the sustainable development goals (SDGs; United Nations [UN], 2015) constitute the most ambitious programme in history to confront societal challenges (Ramos, Caeiro, Moreno Pires, \& Videira, 2018), covering social and economic development issues. Buckley, Doh, and Benischke (2017) encourage addressing these grand challenges at the company-society interface by focusing on CSR and the developmental role of MNCs in emerging countries (Kolk \& Van Tulder, 2006). However, the political CSR frame (Frynas \& Stephens, 2015) fails to examine the motivations and ultimate consequences on society's grand challenges of the CSR construct. This gap provides an opportunity to analyse the institutional drivers and social outcomes that a specific subset of political CSR strategies may exert in the development of emerging countries. In addition, it brings the opportunity to examine the institutional changes that may be associated to sustainable development (Redclift \& Springett, 2015).

The notion of institutional void (IV; Khanna \& Palepu, 1997) refers to the institutional weaknesses that MNCs confront when expanding in developing countries (Doh, Rodrigues, Saka-Helmhout, \& Makhija, 2017). Nevertheless, this concept is mainly oriented to its effects on the company (at a micro level), but it fails to explain the consequences 
of MNCs' activity on the economic development of the host country (at a macro level). The institutional necessity (IN) approach (Forcadell \& Aracil, 2017) tries to overcome this research vacuum. This constitutes a particular type of IV associated to the wide idea of sustainable development, which involves pressing needs (Brundtland Report, 1987). As one step forward, we propose the concept of CSR aimed at institutional necessities (CSRIN) to identify CSR strategies that seek to alleviate specific INs. CSRIN actions improve social conditions and are expected to propel institutional change. Institutional entrepreneurship is a key feature under the CSRIN umbrella. This consists in improving institutions, in some cases using multistakeholder participation, which may be crucial in the advancement towards sustainable development. In this respect, CSRIN activities present the potential to improve people's lives in a lasting way by reshaping institutions. Moreover, the CSRIN perspective considers MNCs as key entrepreneurial agents, evolving the traditional institutional approach that emphasizes the adaptation of the firm towards a focus on active agency (Cantwell, Dunning, \& Lundan, 2010; Kostova, Roth, \& Dacin, 2008; Meyer, 2004). Thus, CSRIN strategies imply a co-evolution of the firm and its institutional environment, resulting in mutual prosperity (Forcadell \& Aracil, 2017) for both the company and its emerging host country.

We base our argumentation on prior studies (Cantwell et al., 2010; Meyer, 2004) that consider the interaction among institutions, MNCs, and developing countries. Empirically, we present three exploratory case studies of large MNCs with strong presence in emerging markets to shed light on the operationalization of the CSRIN notion. We find some patterns of institutional entrepreneurship that addresses the prevailing needs of the host country. This is materialized by multistakeholder initiatives and subsidiary entrepreneurship and by leveraging the interconnection of the different institutional dimensions. Finally, we illustrate how the outcomes of this specific type of CSR, namely, CSRIN, scale up from the corporate level to the macro level, thus contributing to sustainable development.

CSRIN may contribute to expanding the boundaries of the CSR notion by incorporating developmental concerns. Furthermore, CSRIN may help to frame the needs of developing countries and the suitable corporate sustainable strategies more accurately than the wider concept of CSR. From a practitioners' point of view, it may assist companies to focus their efforts towards an enduring social impact. As such, this exploratory study extends the nascent literature on how the SDGs serve to legitimate the development agendas of emerging countries (Diaz-Sarachaga, Jato-Espino, \& Castro-Fresno, 2018) and how MNCs can contribute to mitigate societies' grand challenges (Buckley et al., 2017).

\section{2 | CSR ORIENTED TO INSTITUTIONAL NECESSITIES}

Institutions constitute the key element that influences environmental, social, and economic conditions in emerging countries. Formal and informal institutions (Stephan, Uhlaner, \& Stride, 2015) motivate firms' strategic choices (Doh et al., 2017; North, 1990; Zheng \& Wang, 2014) and their success when entering into developing countries
(Rottig, 2016). However, there are specific conditions under which institutions may either not work or not exist, thus generating IVs (Khanna \& Palepu, 1997). A distinct characteristic of emerging markets is the existence of IVs, specifically related to formal or regulative institutions (Rivera-Santos, Rufín, \& Kolk, 2012), which may lead to a lack of enforcement (Viswanathan \& Rosa, 2010), corruption (Cuervo-Cazurra, 2016; Montiel, Husted, \& Christmann, 2012), transaction uncertainty and market instability (Gao, Jones, Zuzul, \& Khanna, 2017), and increase business risk overall (Banerjee, Oetzel, \& Ranganathan, 2006). The need to respond to IVs directly affects how foreign companies behave in specific institutional contexts and it may help to explain why firms' strategies differ across countries (Doh et al., 2017).

In turn, the effective management of complex institutional environments by MNCs involves market and non-market strategies (Boddewyn, 2003). Existing literature has widely examined market responses to IVs (e.g., Chang \& Hong, 2000; Siegel, 2009). However, non-market strategies to fill IVs have gained only minor attention from academics despite their relevance in helping to mitigate those voids (Cantwell et al., 2010). Non-market actions such as CSR (El Ghoul, Guedhami, \& Kim, 2017) relate to non-economic activities (Doh et al., 2017), pursuing non-economic objectives such as social wellbeing (Boddewyn \& Doh, 2011).

CSR is influenced by the institutional contexts in which firms operate (Arya \& Zhang, 2009; Brammer, Pavelin, \& Porter, 2009; Campbell, 2006, 2007; Zhao, Tan, \& Park, 2014). In order to identify specific IVs and their connection to CSR, the institutional literature proposes an analysis based on the National Business Systems (NBS; loannou \& Serafeim, 2012). The NBS framework includes the categories of politics, education, labour, and finance in specific geographical areas, as IVs can occur in any of these dimensions (Chacar, Newburry, \& Vissa, 2010). In this vein, Jamali and Karam (2018) suggest that the analysis of heterogeneous institutional frameworks through NBS may explain different configurations of CSR across countries.

The notion of IN (Forcadell \& Aracil, 2017; Jamali \& Mirshak, 2007; Yin \& Zhang, 2012) stands for an IV that can potentially be filled or at least mitigated by a company's CSR action, exerting positive effects on external stakeholders (Doh, Littell, \& Quigley, 2010). Thus, the concept of IN serves to focus more precisely on the institutional determinants of firms' CSR in non-enabling contexts. For example, IVs related to the malfunctioning of financial markets lead to financial exclusion (Parmigiani \& Rivera-Santos, 2015), which in turn entails significant institutional needs such as dependence on expensive informal sources and a reduced savings rate (Márquez, Chong, Duryea, Mazza, $\&$ Ñopo, 2007). Likewise, the lack of critical infrastructures (i.e., telecommunications and utility services) constitutes an IV that impedes the fulfilment of basic needs. This limits living standards (World Bank, 2013) and the ability to pursue beneficial opportunities (Rettab, Brik, \& Mellahi, 2009). In turn, IVs in the educational dimension are a major source of IN as illiteracy constitutes a barrier to enter the labour market (Parmigiani \& Rivera-Santos, 2015). Consequently, these social deficits pertaining to the financial, political, and educational institutional dimensions constitute different forms of social constraints that can be considered IN if companies are able to alleviate their effects through sustainable policies. 


\section{1 | From CSR to CSRIN}

Grounded on Jackson and Apostolakou's (2010) motives to engage in CSR-instrumental and normative-we build on two streams of literature analysing the relationship between CSR and IVs. One relates to an instrumental view of CSR, as it focuses on the internal value creation that these corporate actions bring to the firm (Husted \& Allen, 2006; McWilliams \& Siegel, 2001). Complementary to that view, an emerging stream of literature places a greater emphasis on the normative aspects of CSR in developing countries (Chakrabarty \& Bass, 2015; Jackson \& Apostolakou, 2010) as an effective means to fill IVs (Khanna \& Palepu, 2010; Regnér \& Edman, 2014). Thus, the variable of interest is the social value creation (Yin \& Jamali, 2016), which is external to the company and may be related to institutional deficits that can be categorized by using the NBS classification (loannou \& Serafeim, 2012).

Emerging markets show a greater need for CSR due to their weak institutions (Preuss, Barkemeyer, \& Glavas, 2016). In developing countries, either governments are unable to provide basic services for social needs (Aguilera-Caracuel, Guerrero-Villegas, \& García-Sánchez, 2017; Eweje, 2006; Sá de Abreu \& Barlow, 2015) or they lack enforcement, the preponderance of formal institutions being diminished in favour of MNCs (Joutsenvirta \& Vaara, 2015; Scherer, Palazzo, \& Baumann, 2006). MNCs can fill these voids through substitution (Boddewyn \& Doh, 2011; Hiss, 2009; Jackson \& Apostolakou, 2010). By playing a state role and substituting the function of formal institutions (Frynas \& Yamahaki, 2016), firms engage in political CSR (Scherer \& Palazzo, 2011). However, the underlying goal of such activities is to increase MNCs socio-political legitimacy (Shirodkar, Beddewela, \& Richter, 2018), limiting its scope to firm-level determinants and results. In this manner, the political CSR perspective disregards the analysis of the CSR social outcomes (Frynas \& Stephens, 2015) and the influence that corporate actions may exert on other stakeholder groups. Likewise, the shared value perspective (Porter \& Krammer, 2011) fails to explain the institutional motivations and ultimate consequences of corporate actions on society's grand challenges. To fill this gap, we propose the concept of CSRIN, as a specific type of political CSR aimed at filling INs, thus influencing local institutions and contributing to social and economic development. CSRIN actions that provide a solution for a pressing IN include financial products to access the unbanked population (Forcadell \& Aracil, 2017) and responsible lending (Pomering \& Dolnicar, 2009), provision of collective goods (Boddewyn \& Doh, 2011), enhanced environmental consideration (Gao et al., 2017), programmes to confront climate change (Brewer, 2005), and the development of communities' literacy levels (Chapple \& Moon, 2005).

\section{2 | Institutional change and sustainable development}

INs that drive CSRIN activities constitute "opportunity spaces for agency" (El Ghoul et al., 2017; Mair \& Martí, 2009; McKague, Zietsma, \& Oliver, 2015; Venkataraman, Vermeulen, Raaijmakers, \&
Mair, 2016). Governments hold the primary responsibility for addressing social necessities, but companies are often compelled to promote institutional transformation through sustainable strategies to counteract those necessities (Mbalyohere, Lawton, Boojihawon, \& Viney, 2017; Yin \& Jamali, 2016). Therefore, CSRIN is expected to generate institutional change (Campbell, 2004; Cantwell et al., 2010; Jamali \& Karam, 2018). Institutional change is the result of firms' reactions to the existing institutions (North, 1990) and connects MNCs with the transformation in the institutional landscape (Cantwell et al., 2010). This developmental character (Duarte, 2010) within the institutional status quo benefits the society (Rodrigo, Duran, \& Arenas, 2016) and constitutes a distinctive attribute of CSRIN strategies.

Moreover, CSRIN exerts a positive effect that exceeds firms' internal domains by positively impacting stakeholders, especially when it is designed as a development tool (Newell \& Frynas, 2007) that transforms the institutional landscape (Duarte, 2010). CSRIN may cover the INs related, for example, to environmental protection or anti-corruption policies, thus showing firms' concern and commitment for the communities (Jain, 2017). Likewise, when producing public goods (Scherer, Palazzo, \& Matten, 2014), firms provide positive externalities to local communities (Boddewyn \& Doh, 2011) and potentially constitute a source of institutional change that leads to further development. Thus, CSRIN helps in explaining the process through which the benefits of CSR at the micro level scale up to the macro level and shapes sustainable development (Shah, Arjoon, \& Rambocas, 2016).

In addition, this strategy has an economic sense for the firm because it generates a positive reputation by signalling MNCs' social actions to various stakeholders (Doh et al., 2017; El Ghoul et al., 2017). In environments where IVs prevail, market participants increasingly rely on company signals and more specifically in the Latin American context (Borda et al., 2017). Furthermore, CSRIN actions create greater value for the firm in environments of weak institutions because stakeholders appreciate the value that the company generates by filling INs. In this manner, substituting for governments and mitigating INs through CSRIN satisfy both ethical and instrumental motivations, as it fulfils the needs of various stakeholder groups (Doh et al., 2010). Thus, CSRIN yields firm-specific economic value creation in addition to context-specific social value creation (Yin \& Jamali, 2016), producing bundles of social and economic value (Dahan, Doh, Oetzel, \& Yaziji, 2010). This type of CSR strategy demonstrates that the normative and instrumental motivations of CSR can work in tandem (Schreck, van Aaken, \& Donaldson, 2013), providing "winwin" situations for both firms and society (Meyer, 2015; Pies, Hielscher, \& Beckmann, 2009).As continual transition in the institutional environment is a typical condition within emerging markets (Rottig, 2016), MNCs' strategies and institutions co-evolve over time. Co-evolution occurs by the interlinkage of two evolutionary processes, and it is frequently used in the sustainable development literature because it involves changes in needs and institutions, among others (Kemp, Loorbach, \& Rotmans, 2007). In this dynamic, besides simply adjusting to hosts' circumstances, firms promote changes in their surrounding institutions through their strategies CSR (Moon, 2007). This strategy of institutional entrepreneurship implies a mutual 
adaptation that legitimates the MNC in the host country, whereas the country itself benefits from the positive institutional effects that the company can produce. In this manner, MNCs become agents of change and participate in the dynamic evolutionary process of sustainable development.

Furthermore, North (1990) and Nelson (2002) consider that institutions are designed to address the issues of long-term economic development. Meyer (2004) concludes that corporate strategies, social issues, and institutional change are interdependent and have a positive effect on the development of host countries. Nonetheless, development is about progressive changes that involve multiple transitions, yet it is not about an identifiable end state (Kemp et al., 2007). As a multidimensional and goal-oriented (Bell \& Morse, 2012) process, sustainable development cannot "be translated into the narrow terms of static optimization" (Kemp et al., 2007, p. 2), and its outcomes "are less prone to statistical analysis, including institutional designs" (McArthur \& Rasmussen, 2017, p. 142). In this manner, we suggest a connection between CSRIN and development by using the SDGs. This follows Kolk's (2016) association of different SDGs to specific sustainable strategies aimed at promoting enduring effects on the social and economic dimensions of development. In this vein, and according to Perez-Batres, Doh, Miller, and Pisani (2012), sustainable development constitutes a broader concept that represents a macro or aggregated view in contrast to the CSR notion that allows the analysis of sustainable actions at the company level. Moreover, the attainment of the SDGs requires the advancement of institutions (Asadullah \& Savoia, 2018) as broader societal changes can be spurred by changes in institutions (UN, 2016). This is explicitly contemplated in SDG 16 "peace, justice and strong institutions" aimed at building effective institutions at all levels, especially in developing countries (UN, 2015).

By seeking enduring goals, CSRIN actions propel institutional change (Cantwell et al., 2010) related to the attainment of the UN's specific SDGs. For example, CSRIN actions seeking to increase financial access through microfinance (Chakrabarty \& Bass, 2015; Forcadell \& Aracil, 2017) may be associated with SDGs $1,{ }^{1} 5$, and 8. Firms' actions aimed at improving infrastructure services (Doh et al., 2010) relate to SDGs 8 and 9, and CSRIN policies designed to ameliorate educational levels may connect to SDGs 1,8 , and 10. Thus, CSRIN-driven institutional change in particular NBS areas, such as financial or educational, may be related to the SDGs (UN, 2015), which are crucial for achieving social and economic development.

In light of the above discussion, we suggest the following research questions regarding CSRIN as a catalyst for institutional change and sustainable social and economic development:

Research question 1. Do CSRIN strategies favour institutional change in emerging host countries?

Research question 2. By inducing institutional change, do CSRIN strategies propel the sustainable development of emerging countries?

${ }^{1}$ Descriptions of the SDGs are available at https://sustainabledevelopment.un. org.

\section{3 | RESEARCH DESIGN}

\section{1 | Methodology}

We use a comparative case study technique (Yin, 2003), which is appropriate for our purposes as it can reveal the particularities of a complex social situation (Denscombe, 2014). Furthermore, our multiple-case design brings additional robustness to a single-case design. The cases illustrate the potential different institutional impacts of CSRIN strategies, thus ensuring variance along the various institutional dimensions (Eisenhardt, 1989). This allows the identification and in-depth analysis of the research goals: (a) how MNCs contribute to institutional change when dealing with INs in host countries and (b) whether these corporate strategies facilitate sustainable development in those areas. For this purpose, we start by contextualizing Mexico's institutional environment through the NBS framework. Within each NBS category, we identify the existence of IVs and necessities. Second, by interviewing top managers and analysing secondary data, we examine the fulfilment of these INs, if any, by different corporate actions. In particular, we design a questionnaire (see Appendix A) aimed at highlighting how the company operationalizes the response to the specific IN, the managerial views concerning motivations and barriers, and the results of those actions, with special emphasis on finding how the company measures its social impacts and what are its current limitations in doing so. For each company, the authors personally interviewed senior managers, both in the home country-Spain -and in the host country, Mexico. Overall, we conducted eight indepth interviews recording a total of 25,000 words. In order to avoid self-biased responses, we triangulated our findings with secondary sources of data (Eisenhardt \& Brown, 1998).

An important source of secondary data that we used relates to external ratings of responsibility and reputation assessed by different stakeholders. The former was measured by using Reuters environmental, social and governance (ESG) scores (i.e., Fernandez-Feijoo, Romero, \& Ruiz, 2014). The latter was assessed by Merco, a private research firm that evaluates MNCs' reputation in their Monitor de Reputación Corporativa in each of the countries where these companies are established, as opposed to other reputation measures that provide a single benchmark for each MNC. Merco follows a multistakeholder perspective by interviewing a large sample of different stakeholder groups such as executives, consumers, financial analysts, NGOs, unions, economic journalists, and professors that evaluate firms' reputation in their respective field of expertise. Merco has been shown to be a good measure for corporate reputation (Borda et al., 2017), and its results are audited by KPMG to ensure reliability.

\section{2 | Companies analysed}

We present three in-depth case studies from large MNCs headquartered in Spain that have expanded internationally into emerging markets, including Mexico, where they show a strong presence. The choice of these cases is based on their respective industry groups-financial services, telecommunications, and electric utilities- 
TABLE 1 Companies' figures

\begin{tabular}{|c|c|c|c|}
\hline 2016 & Company A & Company B & Company C \\
\hline Market capitalization (€mn), 12.31.16 & 39,600 & 44,430 & 44,320 \\
\hline Net profit (€mn) & 3 & 2 & 3 \\
\hline Mexico & $16 \%$ of operating profit (generation) & $2.5 \%$ of total revenues & $46.3 \%$ of attributed net profit \\
\hline Employees & 30,591 & 127,323 & 134,792 \\
\hline Mexico & 874 & 2,829 & 37,378 \\
\hline Clients (mn) & 35 & 316 & 70 \\
\hline Mexico & n.a. & 27 & 19 \\
\hline Contribution to the Mexican economy & $25 \%$ of total renewable installed capacity & $27.6 \mathrm{mn}$ total access & $22 \%$ of total banks' assets \\
\hline
\end{tabular}

Source: Companies' Annual Reports 2016.

and their relevance to both the Mexican economy and the achievement of the SDGs. These industries have the potential to contribute to several weaknesses identified through the NBS such as financial exclusion, digital exclusion, and electricity exclusion, respectively (World Bank, 2013). Recently, Mexico's President declared that "Mexico is home to large, well-established Spanish companies that are an integral part of our economic life, such as (company A, B and C)." ${ }^{2}$ According to firms A, B, and C's 2016 annual reports, the bank company is the leader in Mexico in assets and branches. In turn, the telecommunications company analysed holds a $22.8 \%$ market share in the country, whereas the electric utility is the first private energy producer in Mexico. Table 1 provides a description of the key figures from each company that make the three cases suitable for comparison.

\section{3 | INs in Mexico}

Mexico provides an interesting scenario for our study as it is the most populated country in Latin America and the second largest economy in the region in terms of GDP. However, IVs have prevented Mexico from achieving full potential (Hernandez-Trillo, 2016; Iniguez-Montiel, 2014), presenting a GDP per capita much lower than the Organisation for Economic Co-operation and Development (OECD) average and the highest inequities across OECD countries (OECD, 2016).

The analysis of the Mexican institutional environment through the NBS framework (loannou \& Serafeim, 2012) shows pressing needs across different dimensions (Table 2 ) such as very low financial inclusion and Internet penetration, a highly polluting power production mix, and a weak educational level. In particular, financial services in Mexico are mostly satisfied by informal providers at a higher risk and cost. In turn, the digital divide is associated with low Internet penetration, which derives from an underdeveloped telecommunications infrastructure in Mexico (Chen \& Wellman, 2004). Moreover, the fuel-based electricity-generating system produces air pollution with major health effects in Mexico (Bell, Davis, Gouveia, Borja-Aburto, \& Cifuentes, 2006). Finally, concerning education, the National Survey of Dropout in Upper Secondary Education in Mexico (2012) revealed that the main cause of dropout (35\% of respondents) was the lack of financial resources.

However, corruption appears as Mexico's main concern, ranking in the last quartile in the Corruption Perception Survey (Transparency
International, 2016). This is intensified by the pervasive informality of Mexico's economy, where $57 \%$ of workers have informal employment (OECD, 2016), which leads to an absence of workers' labour rights and the lowest tax collection level within OECD countries. In fact, challenging IVs such as informality and reduced government enforcement fosters corruption (Gao et al., 2017). Recently, Pope Francis declared that corruption in Latin America is a "social virus." ${ }^{33}$ Moreover, the prevalence of corruption is considered an IV (Doh \& Guay, 2004) that may be the cause of other voids such as low educational quality, reduced foreign direct investment (Cuervo-Cazurra, 2006), especially in the telecommunications sector (Uhlenbruck, Rodriguez, Doh, \& Eden, 2006), and the provision of collective goods (Boddewyn \& Doh, 2011). In this context, MNCs are relatively well placed to reject corruption in Mexico through internal policies that may relate to the CSR domain (Weyzig, 2006).

\section{4 | Findings from interviews}

This section examines how CSRIN strategies respond to IN in the host country and its effects on institutional change through the achievement of the SDGs.

Company A (Bank): CSR strategy committed to INs related to financial inclusion and education and increasingly focused on environmental sustainability globally. The CEO of this company recently claimed that "investing in social sustainability is part of the banking industry's responsibility," with "full integration of CSR into our business model." We met the Director of Reporting and Sustainability in Spain. In Mexico, we met the Head of Corporate Responsibility and Reputation and the President of the company's Foundation in separate interviews. The bank aims to alleviate major social needs and to operate in alignment with the UN's SDGs. In addition, the Director of Reporting and Sustainability in Spain stated:

We want to go one step further in our alignment with the SDGs. The best way we can contribute to the SDGs is by devoting capital and funding-specific initiatives. In addition, this will show a true commitment of our company, as we are going beyond adhering to specific international agreements such as Equator or UNEP-Fi, in which we have been members for a long time. 
TABLE 2 Mexico institutional analysis-NBS dimensions

\begin{tabular}{|c|c|c|}
\hline & 2010 & 2016 \\
\hline $\begin{array}{l}\text { Domestic credit provided by financial sector } \\
\text { (\% of GDP) }\end{array}$ & 43.9 & 56.4 \\
\hline $\begin{array}{l}\text { Financial inclusion (account holders as \% } \\
\text { of adults) }\end{array}$ & 27.4 & 44 \\
\hline \multicolumn{3}{|l|}{ Political system } \\
\hline $\mathrm{CO}_{2}$ emissions (metric tons per capita) & 3.96 & 3.87 \\
\hline Electric power consumption (kWh per capita) & 1,963 & 2,09 \\
\hline Mobile cellular subscriptions (per 100 people) & 77.5 & 88.2 \\
\hline Individuals using the Internet (\% of population) & 31.1 & 59.5 \\
\hline \multicolumn{3}{|l|}{ Economy } \\
\hline Income share held by lowest $20 \%$ & 4.7 & 5.1 \\
\hline Human development index ranking (over 186 countries) ${ }^{a}$ & \#82 & \#77 \\
\hline \multicolumn{3}{|l|}{ Government } \\
\hline Tax revenue (\% of GDP) & 10.2 & 13.9 \\
\hline Corruption perception ranking (over 180 countries) $^{\mathrm{b}}$ & \#98 & \#135 \\
\hline \multicolumn{3}{|l|}{ Educational and labour system } \\
\hline Education attainment: Lower secondary completion rate (\%) & 78.5 & 79.0 \\
\hline $\begin{array}{l}\text { Enrolment in upper secondary education } \\
\text { (16-year-olds) }\end{array}$ & $65 \%$ & n.a. \\
\hline Student skills (PISA reading test score vs. OECD average) ${ }^{c}$ & 413 vs. 474 & 423 vs. 493 \\
\hline
\end{tabular}

Note. GNI: gross national income; n.a.: not applicable; NBS: National Business Systems; OECD, Organisation for Economic Co-operation and Development; Program for International Student Assessment; PISA: Program for International Student Assessment.

Source: World Bank, except the following:

aUnited Nations;

${ }^{\mathrm{b}}$ Transparency International; and

'OECD.

Bank $A$ is also concerned about the social dimension of sustainability, to which they can contribute by enhancing financial inclusion:

In addition to the important effort of our company in microcredits in Latin America, we are using easy-toopen accounts and digital products that promote financial inclusion. In countries with low banking access such as Mexico, these are the best products to enhance savings and payment security. We try to bridge the gap between financial products offered and population needs.

Our interviewees in Mexico confirmed that "financial inclusion is now digital. Thanks to our multi-platform mobile banking app, out of our 19 million clients in Mexico, 15\% are digital clients." In addition, the bank extends access to the formal financing system in Mexico through the non-banking correspondent business model, which consists in outsourcing agreements with traditional stores to reach more unbanked clients by covering a larger area and longer opening hours. "On reaching 32,000 correspondents we have become the largest bank in Mexico by number of correspondents."
Along the same lines, and to promote social entrepreneurship, the bank runs the largest private microfinance institution in Latin America by number of beneficiaries. "Our Microfinance Foundation has been granted consultative status by the United Nations and is a member of its Private Sector Advisory Panel for 2017-19."

Another key IN in Mexico is education. In this respect, the Director of Reporting and Sustainability stated that "Education is a key focus of our sustainable policies, and in particular financial education for a responsible use of our products."

In this area, we are more focused on emerging markets. In Mexico we run specific courses on the safe use of credit cards with very good returns for both clients and the company. Indeed, these courses have definitely improved financial literacy amongst customers but have also led to a lower rate of non-performing clients and a stronger linkage to the bank.

Another programme related to financial education is Valores de Futuro ("Future Values"), which "aims to improve children's knowledge related to the use of money, such as savings and responsibility." 
In this area, the company stressed that it is committed to general education as well. In Mexico, our two meetings with managers emphasized their concern about low educational levels and the school dropout rate and its connection to corruption and the informal economy. Of note is a project in Mexico called Por los que se quedan ("For those left behind"), aimed at reducing the school dropout rate of children whose parents have migrated to the United States. These scholarships are managed by the bank's Foundation in Mexico, which is the largest educational foundation in Latin America.

The program was born ten years ago. There are high rates of school dropout in areas of intense migration, where in some cases the average school level was only six years. This initiative aims to contribute to zero school abandonment and to ensure more opportunities to talented students. We have granted nearly 74,000 scholarships, for an individual amount that represents $25 \%$ of the student's family income. We monitor the use of this subsidy, with satisfactory results as $97 \%$ of schoolchildren have continued their studies.

Company B (Telecommunications): CSR strategy focused on INs related to digital inclusion, digital education, and the fight against corruption. The company follows a "Plan and Specific Principles of Responsible Business." In the headquarters, we met the Global Director of Corporate Ethics and Sustainability and the Director of Stakeholders Management and Reporting, respectively, whereas in Mexico, we met the Head of Corporate Responsibility and a senior manager of the Foundation. All four managers highlighted how the company addresses social needs through corporate actions attached to the core business:

We contribute to social development as our products exert a leverage effect to obtain other important services. For instance, the Internet connection in rural areas allows enrolling in online education. Conversely, if we were not there, the digital divide between developed and developing economies would be even larger.

Thus, by increasing mobile and broadband access and granting digital access to populations hitherto not connected, Company B may alleviate the digital gap and propel cross-cutting effects to indirectly develop other key sectors.

In this line, the firm works to extend the availability of telecommunication technology to "facilitate profound social changes." As stressed by one interviewee: "We strongly believe that our firm can contribute to reduce inequalities in Mexico by enhancing digital inclusion."

Corruption in Mexico is a relevant concern for Company B, which promotes innovative programmes and actions to combat this issue, such as the Anti-corruption Innovation Award. Another initiative is related to the installation of telecommunications infrastructures in small municipalities where local governments have often demanded bribes from firms in exchange for administrative permits. To avoid this situation, the company has developed with the government a new regulation, which strengthens the installation of more cell towers in state buildings, thus increasing infrastructure and combating corruption.
Also, in order to expand existing telecommunications infrastructures in areas with reduced digital access, they "collaborate with rural entrepreneurs, to share investment costs and returns in what we call Rural Franchises. Sometimes this practice results in Public-Private partnerships, very common in infrastructure projects in developing countries."

Responsible use of technology constitutes another necessity identified by the company in Mexico. The "Digital Trust" programme educates customers in acquiring better skills to use digital technologies such as control of their own personal data, usage, and permits. "This empowers clients as it increases their confidence in the usage of technology." This programme also includes "educating the young population to detect and prevent cyberbullying, kidnappings, etc., as unfortunately, the US, Spain and Mexico are the main producers of infant pornography." In this area, the company also joins efforts with the Mexican government through the initiative Nos importa México ("We care"), seeking to increase digital access in a trustworthy and safe environment. By promoting digital inclusion based on connectivity and educating clients to access these services:

Our activity has a clear impact on SDG \#9, however, our digital solutions are essential to achieve more than half of the proposed SDGs such as growth and education, quality of life and facilitate equitable growth.

Company C (Electric utility): CSR strategy focused on INs related to electricity inclusion. We met with the Director of CSR and with the Innovation, Environment and Quality Manager at the company headquarters. Both highlighted their sustainable energy business model towards de-carbonization. This involves important investments in renewable energies since 2001, accounting already for two-thirds of their generation mix. The company plans to continue leading this transformation by offering reliable and quality energy products, with the lowest environmental impact. Thus, "the major contribution of our company to sustainability is our commitment to wind power, which specifically targets SDG 7 and SDG 13. As an electric utility, we are necessarily concerned about these two specific SDGs because our sector is one of the most polluting and thus we can definitely contribute to mitigating climate change." These comments underpin the company's recent shareholder agreement with the world's largest manufacturer of wind turbines to become a prominent shareholder.

The company has identified specific actions to address these SDGs, specifically focusing on a low-carbon energy mix. "We have committed to reduce our $\mathrm{CO} 2$ emission by $30 \%$ in 2020 with respect to 2007 , by $50 \%$ in 2030 and being emission-neutral in 2050." According to the 2016 annual report, at the moment, its emissions are $34 \%$ below the European average, and $66 \%$ of the company's installed capacity is free of emissions. This directly impacts on SDG 13.

In addition, and related to SDG 7, the company has developed social programmes associated with electricity access in emerging markets where it has a presence. "Our project Electricidad para todos ('Electricity for all') aims to bring electricity access to 4 million clients around the world by 2020, specifically in Brazil and Mexico." This programme has been complemented with further actions to universalize access to telephones and the Internet in partnership with Company B. As stated earlier, these basic needs and their solution tend to overlap and to be interconnected. 
Our interviewees stated that the company's CSR initiatives are transversal and apply to every country where it has a presence. However, it also adapts to local characteristics. In the specific case of Mexico, it is improving the standards prevalent in the country.

This country constitutes our largest investment in renewables in Latin America. The existing electric infrastructure in Mexico is very polluting. We operate combined-cycle power plants, and we are building two large-scale photovoltaic power stations which are more efficient, thus reducing the amount of $\mathrm{CO} 2$ emissions in Mexico. The plant in Santiago (Mexico) is the largest photovoltaic power station in the world built by our company, which proves our commitment to renewable energy in Mexico. In particular, we estimate a reduction of $50 \%$ in $\mathrm{CO} 2$ emissions versus the old plants. Our commitment to switching Mexico's power generation towards less polluting energies is demonstrated by the $15 \%$ of the group's total investments assigned to this country.

In addition, Company $\mathrm{C}$ stated that it works with Company $\mathrm{A}$ (bank) to fund socially responsible projects. For instance, Company A has provided several green loans to Company $\mathrm{C}$, including the largest green loan to date on a global scale, to finance projects linked to energy efficiency and renewable sources. In these transactions, the financing margin is linked to the progress of its $\mathrm{CO}_{2}$ emissions' intensity, as certified by an external environmental agency, which also acknowledges that the proceeds will be allocated in accordance with SDG 7.

\subsection{Quantitative data: Materiality analyses and stakeholder-based reputation assessment}

CSRIN strategies have the potential to proactively engage stakeholders and address their needs. For this reason, we add to our primary-data analysis secondary sources that reflect stakeholders' perception of the reputation of the companies analysed. We measure reputation by the Merco index, which provides a complete assessment of the 100 most reputed firms in each country. Table 3 matches Merco reputation perceptions for the three companies in their home and host country over a 4-year period. We also triangulate our findings by using the ESG assessment as an objective measure of the corporate sustainability efforts during the same period (Table 4). We apply the overall ESG score and specific scores regarding ESG pillars. These dimensions are measured on the basis of 178 different indicators. Reputation perceptions according to Merco are robust across the three cases considered in the home country. However, in the destination country, there are strong differences between them, the bank having the highest reputation. This result is paired by the ESG analysis, where the bank ranks in the best position.

\section{4 | DISCUSSION}

Table 5 summarizes our empirical findings. We draw conclusions from the selected quantitative data (NBS analysis, ESG, and reputation ratings), qualitative information (analysis of interviews), and observation, which is regarded as a valid data source (Eisenhardt \& Graebner, 2007). The three cases illustrate how CSRIN strategies allow to pursue sustainable development in different ways by addressing the various INs in an emerging country context. We found evidence in line with our research questions. More specifically, we found different patterns through which these strategies deliver institutional change and sustainable development: (a) institutional entrepreneurship; (b) multistakeholder initiatives; (c) leveraging the interconnection of the different goals; and (d) subsidiary entrepreneurship.

We found evidence of MNCs' institutional entrepreneurship strategies, aimed at transforming the institutional setting. For example, the bank analysed addresses INs that originate from financial exclusion and low educational levels. Thus, this company provides services that increase financial access, which in turn leads to institutional change and contributes to sustainable development as per its positive effect on SDG 1. Banking products provide a basis for entrepreneurship to escape from poverty and enhance savings. Other CSRIN initiatives of this company include educational programmes that have direct influence on SDG 4. Furthermore, the telecommunications company is focused on the IN produced by digital exclusion. This explains its focus on extending telecommunications infrastructures, which definitely provides institutional change through the direct attainment of SDG 9. Finally, the electric utility firm directly addresses INs that appear as a result of the lack of access to electric power. Furthermore, the company extensively invests in renewable energies, thus combating pollution levels. Both CSRIN actions lead to institutional change that can be measured through the incidence of environmental SDGs (7 and 13).

TABLE 3 Corporate reputation perceived by stakeholders at home and host country

\begin{tabular}{|c|c|c|c|c|}
\hline Merco rank (highest score: 1 ) & & Company A & Company B & Company C \\
\hline Reputation host (Mexico) & $\begin{array}{l}2016 \\
2015 \\
2014 \\
2013\end{array}$ & $\begin{array}{l}18 \\
45 \\
34 \\
26\end{array}$ & $\begin{array}{l}50 \\
36 \\
45 \\
45\end{array}$ & $\begin{array}{l}N / A \\
N / A \\
N / A \\
97\end{array}$ \\
\hline Reputation home (Spain) & $\begin{array}{l}2016 \\
2015 \\
2014 \\
2013\end{array}$ & $\begin{array}{l}4 \\
6 \\
6 \\
7\end{array}$ & $\begin{array}{l}6 \\
5 \\
5 \\
6\end{array}$ & $\begin{array}{l}8 \\
7 \\
7 \\
5\end{array}$ \\
\hline
\end{tabular}

Note. N/A: not applicable.

Bold denotes best annual scores across companies. 
TABLE 4 ESG assessment

\begin{tabular}{|c|c|c|c|c|}
\hline Highest score: 100 & & Company A & Company B & Company C \\
\hline ESG score & $\begin{array}{l}2016 \\
2015 \\
2014 \\
2013\end{array}$ & $\begin{array}{l}49.98 \\
88.42 \\
92.25 \\
88.18\end{array}$ & $\begin{array}{l}50.05 \\
39.38 \\
38.16 \\
45.46\end{array}$ & $\begin{array}{l}47.64 \\
40.29 \\
77.18 \\
42.6\end{array}$ \\
\hline Social pillar score (work force, human rights, community, and product responsibility) & $\begin{array}{l}2016 \\
2015 \\
2014 \\
2013\end{array}$ & $\begin{array}{l}88.40 \\
93.35 \\
90.60 \\
88.95\end{array}$ & $\begin{array}{l}93.91 \\
81.03 \\
80.38 \\
75.80\end{array}$ & $\begin{array}{l}90.88 \\
91.10 \\
88.33 \\
86.98\end{array}$ \\
\hline Environmental pillar score (resource use, emissions, and innovation) & $\begin{array}{l}2016 \\
2015 \\
2014 \\
2013\end{array}$ & $\begin{array}{l}89.23 \\
92.74 \\
92.39 \\
89.99\end{array}$ & $\begin{array}{l}86.39 \\
85.85 \\
85.87 \\
85.54\end{array}$ & $\begin{array}{l}68.38 \\
71.63 \\
72.65 \\
75.43\end{array}$ \\
\hline
\end{tabular}

Note. CSR: corporate social responsibility; ESG: environmental, social and governance.

Bold denotes best annual scores across companies.

TABLE 5 Institutional change provided by CSRIN strategies

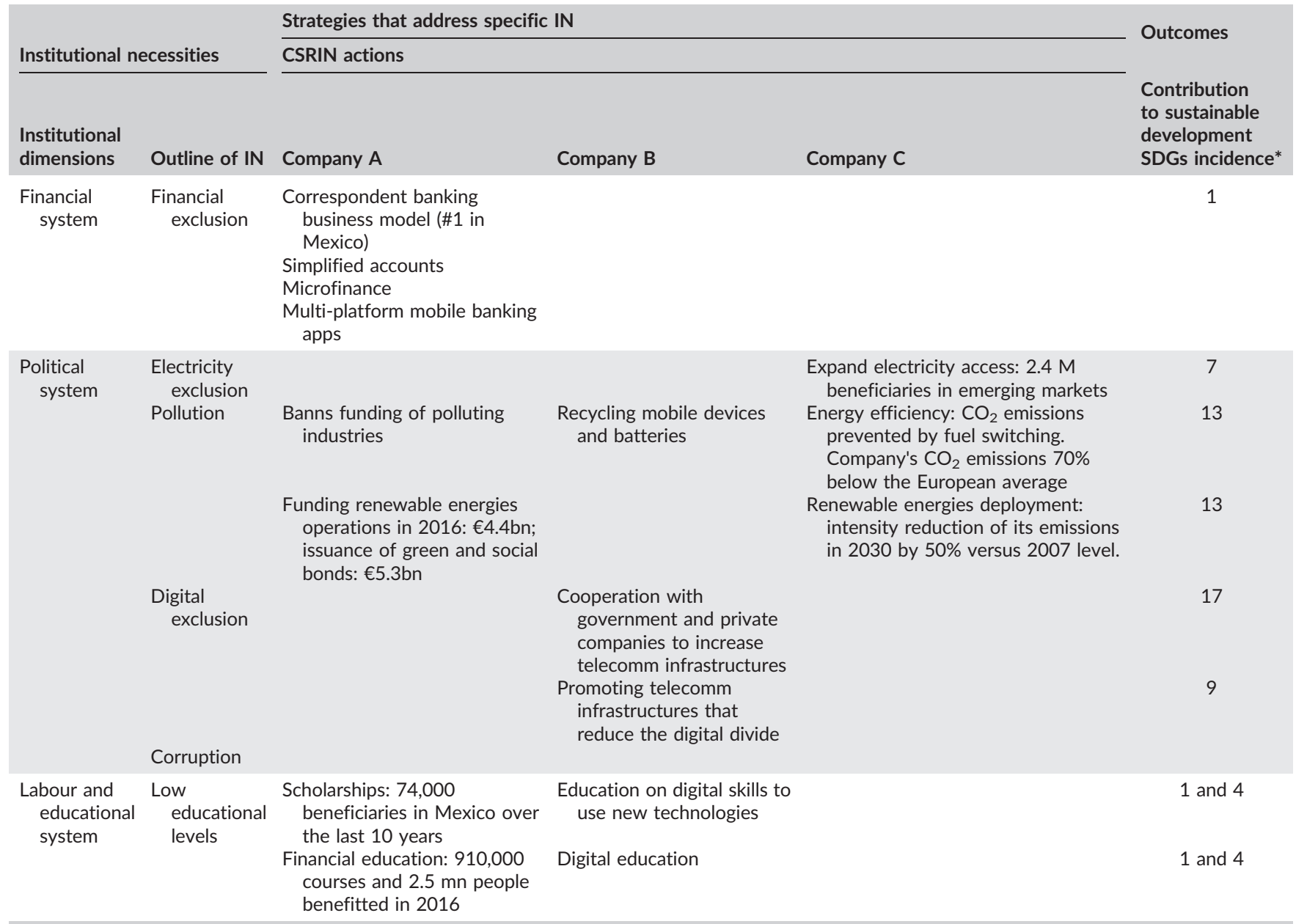

Note. CSRIN: corporate social responsibility aimed at institutional necessities; IN: institutional necessity; SDGs: sustainable development goals.Source: Companies A, B, and C Annual Reports (2016) and findings from interviews.

MNCs tend to join efforts with local governments or other firms and small entrepreneurs in their CSRIN actions, collaborating in the achievement of several SDGs. In particular, the bank contributed to the funding of Company C's clean investments, and Company B has been building telecom infrastructures through the private-public partnership formula. These alliances exert institutional change by 
TABLE 6 SDG contribution. Measurement at macro and micro level

\begin{tabular}{|c|c|c|c|c|}
\hline SDG & & Indicators at the macro level (World Bank) & Indicators at the organizational level & Company \\
\hline No poverty & 1 & Number of people living below $\$ 1.9 /$ day & Financial inclusion: 5.6 million clients in Mexico & A \\
\hline Quality education & 4 & Gross enrolment ratio & 30,000 grants in Mexico (2017) & A \\
\hline Climate action & 13 & Annual $\mathrm{CO}_{2}$ emissions & $\begin{array}{l}\text { The company's } \mathrm{CO}_{2} \text { emissions } 70 \% \text { below the average for the } \\
\text { European industry } \\
\text { Reduce company emissions in } 2030 \text { by } 50 \% \text { versus } 2007 \\
\text { levels and to become carbon neutral by } 2050 \\
\text { Close all of its coal-fired power plants } \\
\text { The largest photovoltaic power station built by the company } \\
\text { in the world can be found in Mexico. }\end{array}$ & C \\
\hline
\end{tabular}

Note. SDG: Sustainable Development Goal. Source: World Bank (2018); companies reports.

simultaneously meeting different IN and have an impact on SDG 17 , among others.

The institutional context is complex and multidimensional, as evidenced by the interconnection between different SDGs. This means that, through the direct attainment of a particular SDG, companies can contribute to other SDGs indirectly. For example, corruption has been found as a major IN in Mexico that influences other institutional weaknesses. As a response, we find CSRIN strategies in the three cases aimed at combating corruption through different approaches. These may lead to major institutional changes that can indirectly mitigate other challenges measured by the SDGs. For example, by enhancing financial inclusion in Mexico, Company A contributes to institutional change in the financial dimension and indirectly pursues SDG 1. Company B extends telecommunications access to reduce the digital divide, which indirectly combats corruption. Finally, both companies deploy intensive CSRIN actions aimed at promoting education, which directly impacts on SDG 4 and thus exerts institutional change in the educational dimension and, indirectly, in the labour dimension.

We consider the different views of managers based both at the headquarters in Spain and in the subsidiaries in Mexico. Similarly, we compare ESG and reputation ratings in both the home and the host country. In this respect, we observe a considerable alignment between the managerial views of CSR in the headquarters and the subsidiary. However, we also found ad hoc strategies aimed at the specific institutional setting of the host country, thus following patterns of subsidiary entrepreneurship and innovative initiatives. In particular, we observe an important degree of freedom to adapt the general policies of CSR stated by the headquarters to the local reality. This is particularly notable in the financial company, which concentrates on specific actions tailored to the destination country that enhance financial inclusion.

The analysis of the ratings related to ESG performance and reputation perceived by stakeholders reinforces the above findings, as it represents the views of external third parties. First, the perceived reputation in the home country is stronger than in the subsidiaries in all three cases, with slight differences among them. This may well reflect the liability of foreignness and the difficulty that MNCs have to legitimize themselves when operating abroad. Yet the bank holds the best perceived reputation in the host country rankings among the three companies. As we measure reputation based on stakeholders' perception, we may suggest that sustainable strategies by this company are closer, and more aligned, to stakeholders' interests. In fact, the bank is the company most focused on specifically tailoring its CSR to the needs of the destination country. Thus, the reputational benefit of engaging in CSR is contingent on institutional factors (Borda et al., 2017), more specifically, to addressing the host country's INs. Moreover, we suggest that institutional entrepreneurship accompanied by subsidiary entrepreneurship strategies amplifies the reputational stakeholder perception. Second, when the ESG criteria are considered, the bank holds pre-eminent positions, nearly doubling the scores obtained by Companies B and C. More specifically, Company $B$ does not show specific measurement of their sustainable actions, whereas Company $C$ does not provide sustainability targets to subsidiaries, as opposed to Company A. In this respect, the three companies coincide in the difficulty of measuring the impact of their CSR strategies on institutional change and sustainable development. This constitutes an important shortcoming in order to monitor and optimize the company efforts in these areas. Although the World Bank has well established how to measure the achievement of the SDGs at a macro level, companies are still developing standards for sizing their impacts at the organizational level (Table 6).

\section{5 | CONCLUSIONS}

To the best of our knowledge, this is the first analysis that links corporate sustainability strategies in developing countries with the institutional change that it provides and its potential to promote sustainable development in these regions. Overall, our study shows that CSRIN consists in a specific CSR action, which stresses the role of MNCs as developmental agents (Blowfield \& Dolan, 2014) becoming "part of the solution" (Wright \& Nyberg, 2017) to major social challenges (Buckley et al., 2017). However, both institutional change and economic development are made up of continuous transitions, where MNCs' CSR constitute only a piece in a wider process of change 
shaped by the actions of different stakeholders, such as government, NGOs, and local actors. In this line, our findings also suggest that some major institutional failures in emerging markets need to be solved in collaboration between companies, social, and political agents. This is shown by the agreements of Companies $\mathrm{A}$ and $\mathrm{C}$ for funding projects that allow a reduction in greenhouse gas emissions and in Company B's CSRIN strategies to fight against corruption by reaching agreements with the government. These multistakeholder initiatives extend the previous findings of Doh et al. (2010) on public-private partnership in emerging markets and also Davila, Rodriguez-Lluesma, and Elvira (2018), who analyse the Latin American MNCs' stakeholders' engagement in the same institutional context.

The CSRIN perspective shows how MNCs can co-evolve their CSR strategies with the institutional landscape rather than simply adapting or accommodating to it as a form of external pressure (Buckley et al., 2017; Cantwell et al., 2010). This might seem paradoxical, though prior studies (Meyer, 2004) suggest a combination of MNCs' adaptation with simultaneous influence on the institutional environment. Cantwell et al. (2010) associate institutional entrepreneurship with an increasing autonomy of MNCs' subsidiaries, arising from the institutional duality (Jamali \& Neville, 2011) faced by the parent company and the subsidiary. For example, we find evidence that reinforces this view in Company A's educational programme "For those left behind," which constitutes a CSR initiative specifically tailored to the Mexican institutional environment. Our study shows that those companies that design specific measures in the destination countries to deal with institutional needs in that particular region are perceived as having a strong reputation by their stakeholders.

Moreover, we find that the institutional landscape of the country analysed shows interrelations between different institutional dimensions (Parmigiani \& Rivera-Santos, 2015). For instance, corruption limits the development of other institutional realities (Jetter \& Parmeter, 2018). These institutional needs can be directly or indirectly mitigated by companies providing institutional change. As such, we find that a particular CSRIN action can strengthen multiple institutional areas. For example, better access to telecommunications services can improve educational levels, and electric power infrastructures can enhance safety at night. Thus, the achievement of institutional change and progress through the network of SDGs requires thinking beyond sectors to deal with institutional interactions. This illustrates North's (1990) findings regarding the evolutionary process of development and the lags between the changes in different institutional dimensions. However, there is little academic evidence on the linkage between different SDGs and their connections to multiple institutional perspectives (Le Blanc, 2015). Thus, further attention to the interrelations between NBS dimensions and SDGs is required in order to better understand the institutional realities and improve the developmental outcomes of CSR activities.This exploratory paper makes a number of contributions to further analysis in the field of the SDGs, and the preceding millennium development goals, as effective instruments to deal with society's major challenges (Buckley et al., 2017; Dalgaard \& Erickson, 2009; Fukuda-Parr, Greenstein, \& Stewart, 2013). In particular, we respond to one of the research questions proposed by Oldekop et al. (2016) for the 2015 post-development agenda by examining how sustainable and responsible business practices impact on development outcomes. Additionally, we follow the Buckley et al. (2017) recommendation for using SDGs to analyse the impact of MNCs' CSR on societies' major challenges. Moreover, by shedding light on how MNCs deal with IVs, we extend prior findings mostly focused on the positive outcomes for the firm (Wang \& CuervoCazurra, 2017), towards an emphasis on the external or social effects. This fills the Schreck et al. (2013) call for investigations of "win-win" strategies that serve firms' interests and those of the society.

Overall, we contribute to the CSR literature by proposing the notion of CSRIN, which allows for a better understanding of CSR determinants and outcomes in the presence of institutional weaknesses. Furthermore, we extend existing evidence about CSR activities to developing countries (Blowfield \& Frynas, 2005; Jamali \& Mirshak, 2007; Jamali \& Neville, 2011; Muller \& Kolk, 2009; Yin \& Zhang, 2012), where the major challenges differ from those in the developed world (Visser, 2008). In addition, we contribute to the institutional literature by applying the NBS framework to Latin American countries, scarcely applied before (Forcadell \& Aracil, 2017; Sá de Abreu \& Barlow, 2015). We argue that CSRIN actions involve institutional agency, as per the deep changes experienced in key institutions where IN prevails. Thus, we extend prior findings on institutional change influenced by MNCs (Campbell, 2004; Cantwell et al., 2010; North, 1990). Finally, our framework combines firm-level responses to challenging institutional deficits with macro-level institutional change measured by the SDGs. In this manner, we follow Wang, Tong, Takeuchi, and George's (2016) identification of new research directions that encompass CSR and the major challenges for society.

A major limitation that we faced in our empirical analysis was the difficulty that companies acknowledge in measuring their sustainability impacts and providing quantitative indicators of their contribution to the different SDGs. Nevertheless, quantifying helps companies to take better decisions in the resources they manage and to direct efforts most effectively. Therefore, the measurement of the impact of CSRIN is essential to the monitoring, design, and communication of these strategies. This should constitute an important area of focus from a managerial perspective, as we noted that the company that provides a more detailed analysis of its social impacts enjoys superior recognition from its stakeholders-enhanced reputation-and a greater control of its ESG risks. Also, the measurement of the impact of CSRIN activities is essential both to generate the necessary feedback about the efficiency of the efforts made by the company and to design useful CSR strategies.

One single-country case study may be non-generalizable. However, case studies show greater validity (Ullah, Jamali, \& Harwood, 2014) than quantitative studies due to their broad analytical approach. Rich contextualization methods, such as qualitative studies, allow to acknowledge the complexity surrounding the particular settings of emerging countries (Teagarden, Von Glinow, \& Mellahi, 2018). The findings, albeit drawn from a small sample, highlight common features in national institutions across the developing world. Nevertheless, further evidence in other countries is desirable to complement these preliminary findings. We also call for empirical studies on emerging MNCs' CSR practices outside their home country to further investigate their influence on the progress of their host economies. Another important future line of research may consider extending our findings 
on the collaboration between government, companies, and social parties for the development of institutions in emerging markets. In sum, for a successful participation of MNCs in the institutional transformation of developing countries, we suggest that the CSRIN perspective opens interesting avenues for research that can contribute to a better understanding of CSR actions and can effectively guide sustainable strategies for those MNCs that wish to alleviate pressing social needs in developing countries.

\section{FUNDING}

This paper has been supported by Projects ECO2015-67434-R and ECO2016-75379-R (MINECO/FEDER) of the Spanish Ministry of Economy and Competitiveness.

\section{CONFLICT OF INTEREST}

The authors declare that they have no conflicts of interest.

\section{ORCID}

Francisco Javier Forcadell (D) https://orcid.org/0000-0003-0145-1842

Elisa Aracil (D) https://orcid.org/0000-0002-8413-8204

\section{REFERENCES}

Aguilera-Caracuel, J., Guerrero-Villegas, J., \& García-Sánchez, E. (2017). Reputation of multinational companies. European Journal of Management and Business Economics, 26(3), 329-346.

Arya, B., \& Zhang, G. (2009). Institutional reforms and investor reactions to CSR announcements: Evidence from an emerging economy. Journal of Management Studies, 46(7), 1089-1112.

Asadullah, M., \& Savoia, A. (2018). Poverty reduction during 1990-2013 Did millennium development goals adoption and state capacity matter? World Development, 105, 70-82.

Banerjee, S. G., Oetzel, J. M., \& Ranganathan, R. (2006). Private provision of infrastructure in emerging markets: Do institutions matter? Development and Policy Review, 24(2), 175-202.

Bell, M. L., Davis, D. L., Gouveia, N., Borja-Aburto, V. H., \& Cifuentes, L. A. (2006). The avoidable health effects of air pollution in three Latin American cities: Santiago, Sao Paulo, and Mexico City. Environmental Research, 100(3), 43-440.

Bell, S., \& Morse, S. (2012). Sustainability indicators: Measuring the immeasurable? London: Routledge.

Blowfield, M., \& Dolan, C. S. (2014). Business as a development agent: Evidence of possibility and improbability. Third World Quarterly, 35(1), 22-42.

Blowfield, M., \& Frynas, J. G. (2005). Setting new agendas: Critical perspectives on corporate social responsibility in the developing world. International Affairs, 81(3), 499-513.

Boddewyn, J., \& Doh, J. P. (2011). Global strategy and the collaboration of MNEs, NGOs, and governments for the provisioning of collective goods in emerging markets. Global Strategy Journal, 1(3-4), 345-361.

Boddewyn, J. J. (2003). Understanding and advancing the concept of nonmarket. Business \& Society, 42(3), 297-327.

Borda, A., Newburry, W., Teegen, H., Montero, A., Nájera-Sánchez, J. J., Forcadell, F., ... Quispe, Z. (2017). Looking for a service opening: Building reputation by leveraging international activities and host country context. Journal of World Business, 52(4), 503-517.

Brammer, S. J., Pavelin, S., \& Porter, L. A. (2009). Corporate charitable giving, multinational companies and countries of concern. Journal of Management Studies, 46(4), 575-596.

Brewer, T. L. (2005). Business perspectives on the EU emissions trading scheme. Climate Policy, 5(1), 137-144.
Brundtland Report, Our Common Future (1987). Report for the World Commission on Environment and Development. United Nations. Oslo.

Buckley, P. J., Doh, J. P., \& Benischke, M. H. (2017). Towards a reinassance in international business research? Big questions, grand challenges, and the future of IB scholarship. Journal of International Business Studies, 48(9), 1045-1064.

Campbell, J. L. (2004). Institutional change and globalization. New Jersey: Princeton University Press.

Campbell, J. L. (2006). Institutional analysis and the paradox of corporate social responsibility. American Behavioral Scientist, 49(7), 925-938.

Campbell, J. L. (2007). Why would corporations behave in socially responsible ways ? An of corporate theory institutional social responsibility Academy of Management Review, 32(3), 946-967.

Cantwell, J., Dunning, J. H., \& Lundan, S. M. (2010). An evolutionary approach to understanding international business activity: The coevolution of MNEs and the institutional environment. Journal of International Business Studies, 41(4), 567-586.

Casson, M. C., Della Giusta, M., \& Kambhampati, U. S. (2010). Formal and informal institutions and development. World Development, 38(2), 137-141.

Chacar, A. S., Newburry, W., \& Vissa, B. (2010). Bringing institutions into performance persistence research: Exploring the impact of product, financial, and labor market institutions. Journal of International Business Studies, 41(7), 1119-1140.

Chakrabarty, S., \& Bass, A. E. (2015). Comparing virtue, consequentialist, and deontological ethics-based corporate social responsibility: Mitigating microfinance risk in institutional voids. Journal of Business Ethics, 126(3), 487-512.

Chang, S. J., \& Hong, J. (2000). Economic performance of group-affiliated companies in Korea: Intragroup resource sharing and internal business transactions. Academy of Management Journal, 43(3), 429-448.

Chapple, W., \& Moon, J. (2005). Corporate social responsibility (CSR) in Asia a seven-country study of CSR web site reporting. Business \& Society, 44(4), 415-441.

Chen, W., \& Wellman, B. (2004). The global digital divide-within and between countries. IT \& Society, 1(7), 39-45.

Cuervo-Cazurra, A. (2006). Who cares about corruption? Journal of International Business Studies, 37(6), 807-822.

Cuervo-Cazurra, A. (2016). Corruption in international business. Journal of World Business, 51(1), 35-49.

Dahan, N. M., Doh, J. P., Oetzel, J., \& Yaziji, M. (2010). Corporate-NGO collaboration: Co-creating new business models for developing markets. Long Range Planning, 43(2-3), 326-342.

Dalgaard, C. J., \& Erickson, L. (2009). Reasonable expectations and the first millennium development goal: How much can aid achieve? World Development, 37(7), 1170-1181.

Davila, A., Rodriguez-Lluesma, C., \& Elvira, M. M. (2018). Engaging stakeholders in emerging economies: The case of multilatinas. Journal of Business Ethics, 1-16, 949-964.

Denscombe, M. (2014). The good research guide: For small-scale social research projects. UK: McGraw-Hill Education.

Diaz-Sarachaga, J. M., Jato-Espino, D., \& Castro-Fresno, D. (2018). Is the sustainable development goals (SDG) index an adequate framework to measure the progress of the 2030 Agenda? Sustainable Development. (forthcoming). https://doi.org/10.1002/sd.1735

Doh, J. P., \& Guay, T. R. (2004). Globalization and corporate social responsibility: How non-governmental organizations influence labor and environmental codes of conduct. Management and International Review, 2, 7-29.

Doh, J. P., Howton, S. D., Howton, S. W., \& Siegel, D. S. (2010). Does the market respond to an endorsement of social responsibility? The role of institutions, information, and legitimacy. Journal of Management, 36(6), 1461-1485. 
Doh, J. P., Rodrigues, S., Saka-Helmhout, A., \& Makhija, M. (2017). International business responses to institutional voids. Journal of International Business Studies, 48(3), 293-307.

Duarte, F. (2010). Working with corporate social responsibility in Brazilian companies: The role of managers' values in the maintenance of CSR cultures. Journal of Business Ethics, 96(3), 355-368.

Eisenhardt, K. M. (1989). Building theories from case study research. Academy of Management Review, 14(4), 532-550.

Eisenhardt, K. M., \& Brown, S. L. (1998). Competing on the edge: Strategy as structured chaos. Long Range Planning, 31(5), 786-789.

Eisenhardt, K. M., \& Graebner, M. E. (2007). Theory building from cases: Opportunities and challenges. Academy of Management Journal, 50(1), 25-32.

El Ghoul, S., Guedhami, O., \& Kim, Y. (2017). Country-level institutions, firm value, and the role of corporate social responsibility initiatives. Journal of International Business Studies, 48(3), 360-385.

Eweje, G. (2006). The role of MNEs at work in Nigeria and South Africa. Business \& Society, 45(2), 93-129.

Fernandez-Feijoo, B., Romero, S., \& Ruiz, S. (2014). Effect of stakeholders' pressure on transparency of sustainability reports within the GRI framework. Journal of Business Ethics, 122(1), 53-63.

Forcadell, F. J., \& Aracil, E. (2017). Sustainable banking in Latin American developing countries: Leading to (mutual) prosperity. Business Ethics: A European Review, 26(4), 382-395.

Frynas, J. G., \& Stephens, S. (2015). Political corporate social responsibility: Reviewing theories and setting new agendas. International Journal of Management Reviews, 17(4), 483-509.

Frynas, J. G., \& Yamahaki, C. (2016). Corporate social responsibility: Review and roadmap of theoretical perspectives. Business Ethics: A European Review, 25(3), 258-285.

Fukuda-Parr, S., Greenstein, J., \& Stewart, D. (2013). How should MDG success and failure be judged: Faster progress or achieving the targets? World Development, 41, 19-30.

Gao, C., Jones, G., Zuzul, T., \& Khanna, T. (2017). Overcoming institutional voids: A reputation-based view of long run survival. Strategic Management Journal, 38(11), 2147-2167.

Hernandez-Trillo, F. (2016). Poverty alleviation in federal systems: The case of México. World Development, 87, 204-214.

Hiss, S. (2009). From implicit to explicit corporate social responsibility: Institutional change as a fight for myths. Business Ethics Quarterly, 19(3), 433-451.

Husted, B. W., \& Allen, D. B. (2006). Corporate social responsibility in the multinational enterprise: Strategic and institutional corporate social responsibility in the multinational enterprise: Strategic and institutional approaches. Journal of International Business Studies, 37(6), 838-849.

Iniguez-Montiel, A. J. (2014). Growth with equity for the development of Mexico: Poverty, inequality, and economic growth (1992-2008). World Development, 59, 313-326.

Ioannou, I., \& Serafeim, G. (2012). What drives corporate social performance? The role of nation-level institutions. Journal of International Business Studies, 43(9), 834-864.

Jackson, G., \& Apostolakou, A. (2010). Corporate social responsibility in Western Europe: An institutional mirror or substitute? Journal of Business Ethics, 94(3), 371-394.

Jain, T. (2017). Decoupling corporate social orientations: A cross-national analysis. Business \& Society, 56(7), 1033-1067.

Jamali, D., \& Karam, C. (2018). Corporate social responsibility in developing countries as an emerging field of study. International Journal of Management Reviews, 20(1), 32-61.

Jamali, D., \& Mirshak, R. (2007). Corporate social responsibility (CSR): Theory and practice in a developing country context. Journal of Business Ethics, 72(3), 243-262.
Jamali, D., \& Neville, B. (2011). Convergence versus divergence of CSR in developing countries: An embedded multi-layered institutional lens. Journal of Business Ethics, 102(4), 599-621.

Jetter, M., \& Parmeter, C. F. (2018). Sorting through global corruption determinants: Institutions and education matter-Not culture. World Development, 109, 279-294.

Joutsenvirta, M., \& Vaara, E. (2015). Legitimacy struggles and political corporate social responsibility in international settings: A comparative discursive analysis of a contested investment in Latin America. Organization Studies, 36(6), 741-777.

Kemp, R., Loorbach, D., \& Rotmans, J. (2007). Transition management as a model for managing processes of co-evolution towards sustainable development. International Journal of Sustainable Development and World Ecology, 14(1), 78-91.

Khanna, T., \& Palepu, K. (1997). Why focused strategies may be wrong for emerging markets. Harvard Business Review, 75(4), 41-48.

Khanna, T., \& Palepu, K. G. (2010). Winning in emerging markets: A road map for strategy and execution. Boston: Harvard Business Press.

Kolk, A. (2016). The social responsibility of international business: From ethics and the environment to CSR and sustainable development. Journal of World Business, 51(1), 23-34.

Kolk, A., \& Van Tulder, R. (2006). Poverty alleviation as business strategy? Evaluating commitments of frontrunner multinational corporations. World Development, 34(5), 789-801.

Kostova, T., Roth, K., \& Dacin, M. T. (2008). Institutional theory in the study of multinational corporations: A critique and new directions. Academy of Management Review, 33(4), 994-1006.

Le Blanc, D. (2015). Towards integration at last? The sustainable development goals as a network of targets. Sustainable Development, 23(3), 176-187.

Mair, J., \& Martí, I. (2009). Entrepreneurship in and around institutional voids: A case study from Bangladesh. Journal of Business Venturing, 24(5), 419-435.

Márquez, G., Chong, A., Duryea, S., Mazza, J., \& Ñopo, H. (2007). Outsiders? The changing patterns of exlusion in Latin America and the Caribbean. economic and social progress in Latin America. Cambridge, MA: Harvard University Press.

Mbalyohere, C., Lawton, T., Boojihawon, R., \& Viney, H. (2017). Corporate political activity and location-based advantage: MNE responses to institutional transformation in Uganda's electricity industry. Journal of World Business, 52(6), 743-759.

McArthur, J. W., \& Rasmussen, K. (2017). Change of pace: Accelerations and advances during the millennium development goal era. World Development, 105, 132-143.

McKague, K., Zietsma, C., \& Oliver, C. (2015). Market development in least developed countries: Leveraging markets as inhabited institutions. Organization Studies, 36(8), 1063-1093.

McWilliams, A., \& Siegel, D. (2001). Corporate social responsibility: A theory of the firm perspective. Academy of Management Review, 26(1), 117-127.

Meyer, K. E. (2004). Perspectives of multinational enterprises in emerging economies. Journal of International Business Studies, 35(4), 259-276.

Meyer, M. (2015). Positive business: Doing good and doing well. Business Ethics: A European Review, 24(2), 175-197.

Montiel, I., Husted, B. W., \& Christmann, P. (2012). Using private management standard certification to reduce information asymmetries in corrupt environments. Strategic Management Journal, 33(9), 1103-1113.

Moon, J. (2007). The contribution of corporate social responsibility to sustainable development. Sustainable Development, 15(5), 296-306.

Muller, A., \& Kolk, A. (2009). CSR Performance in emerging markets. Evidence from Mexico. Journal of Business Ethics, 85(2), 325-337. 
Nelson, R. R. (2002). Bringing institutions into evolutionary growth theory In Social institutions and economic development (pp. 9-12). Dordrecht: Springer.

Newell, P., \& Frynas, J. G. (2007). Beyond CSR? Business, poverty and social justice: An introduction. Third World Quarterly, 28(4), 669-681.

North, D. C. (1990). A transaction cost theory of politics. Journal of Theoretical Politics, 2(4), 355-367.

Oldekop, J. A., Fontana, L. B., Grugel, J., Roughton, N., Adu-Ampong, E. A., Bird, G. K., ... Sutherland, W. J. (2016). 100 key research questions for the post-2015 development agenda. Development and Policy Review, 34(1), 55-82.

Organisation for Economic Co-operation and Development (2016). OECD Data: https://data.oecd.org/ (accesed 30th July 2018).

Parmigiani, A., \& Rivera-Santos, M. (2015). Sourcing for the base of the pyramid: Constructing supply chains to address voids in subsistence markets. Journal of Operations Management, 33, 60-70.

Perez-Batres, L. A., Doh, J. P., Miller, V. V., \& Pisani, M. J. (2012). Stakeholder pressures as determinants of CSR strategic choice: Why do firms choose symbolic versus substantive self-regulatory codes of conduct? Journal of Business Ethics, 110(2), 157-172.

Pies, I., Hielscher, S., \& Beckmann, M. (2009). Business: An ordonomic approach to corporate citizenship. Business Ethics Quarterly, 19(3), 375-401.

Porter, M. E., \& Kramer, M. R. (2011). The big idea: Creating shared value. Harvard Business Review, 89(1), 2.

Pomering, A., \& Dolnicar, S. (2009). Assessing the prerequisite of successful CSR implementation: Are consumers aware of CSR initiatives? Journal of Business Ethics, 85(2), 285-301.

Preuss, L., Barkemeyer, R., \& Glavas, A. (2016). Corporate social responsibility in developing country multinationals: Identifying company and country-level influences. Business Ethics Quarterly, 26(3), 347-378.

Ramos, T. B., Caeiro, S., Moreno Pires, S., \& Videira, N. (2018). How are new sustainable development approaches responding to societal challenges? Sustainable Development, 26(2), 117-121.

Redclift, M., \& Springett, D. (Eds.) (2015). Routledge international handbook of sustainable development. London: Routledge.

Regnér, P., \& Edman, J. (2014). MNE institutional advantage: How subunits shape, transpose and evade host country institutions. Journal of International Business Studies, 45(3), 275-302.

Rettab, B., Brik, A. B., \& Mellahi, K. (2009). A study of management perceptions of the impact of corporate social responsibility on organisational performance in emerging economies: The case of Dubai. Journal of Business Ethics, 89(3), 371-390.

Rivera-Santos, M., Rufín, C., \& Kolk, A. (2012). Bridging the institutional divide: Partnerships in subsistence markets. Journal of Business Research, 65(12), 1721-1727.

Rodrigo, P., Duran, I. J., \& Arenas, D. (2016). Does it really pay to be good, everywhere? A first step to understand the corporate social and financial performance link in Latin American controversial industries. Business Ethics: A European Review, 25(3), 286-309.

Rottig, D. (2016). Institutions and emerging markets: Effects and implications for multinational corporations. International Journal of Emerging Markets, 11(1), 2-17.

Sá de Abreu, M., \& Barlow, C. Y. (2015). Institutional dynamics and organizations affecting the adoption of sustainable development in the United Kingdom and Brazil. Business Ethics: A European Review, 24(1), 73-90.

Scherer, A. G., \& Palazzo, G. (2011). The new political role of business in a globalized world: A review of a new perspective on CSR and its implications for the firm, governance, and democracy. Journal of Management Studies, 48(4), 899-931.

Scherer, A. G., Palazzo, G., \& Baumann, D. (2006). Global rules and private actors: Toward a new role of the transnational corporation in global governance. Business Ethics Quarterly, 16(4), 505-532.
Scherer, A. G., Palazzo, G., \& Matten, D. (2014). The business firm as a political actor: A new theory of the firm for a globalized world. Business \& Society, 53(2), 143-156.

Schreck, P., van Aaken, D., \& Donaldson, T. (2013). Positive economics and the normativistic fallacy: Bridging the two sides of CSR. Business Ethics Quarterly, 23(2), 297-329.

Shah, K. U., Arjoon, S., \& Rambocas, M. (2016). Aligning corporate social responsibility with green economy development pathways in developing countries. Sustainable Development, 24(4), 237-253.

Shirodkar, V., Beddewela, E., \& Richter, U. H. (2018). Firm-level determinants of political CSR in emerging economies: Evidence from India. Journal of Business Ethics, 148(3), 673-688.

Siegel, D. S. (2009). Green management matters only if it yields more green: An economic/strategic perspective. The Academy of Management Perspectives, 23(3), 5-16.

Stephan, U., Uhlaner, L. M., \& Stride, C. (2015). Institutions and social entrepreneurship: The role of institutional voids, institutional support, and institutional configurations. Journal of International Business Studies, 46(3), 308-331.

Teagarden, M. B., Von Glinow, M. A., \& Mellahi, K. (2018). Contextualizing international business research. Enhancing rigor and analysis. Journal of World Business, 53, 303-306.

Uhlenbruck, K., Rodriguez, P., Doh, J. P., \& Eden, L. (2006). The impact of corruption on entry strategy: Evidence from telecommunication projects in emerging economies. Organization Science, 17(3), 402-414.

Ullah, S., Jamali, D., \& Harwood, I. A. (2014). Socially responsible investment: Insights from Shari'a departments in Islamic financial institutions. Business Ethics: A European Review, 23(2), 218-233.

United Nations (2015). Transforming our world: The 2030 agenda for sustainable development. New York: USA.

United Nations (2016). Global sustainable development report. New York: USA.

Venkataraman, H., Vermeulen, P., Raaijmakers, A., \& Mair, J. (2016). Market meets community: Institutional logics as strategic resources for development work. Organization Studies, 37(5), 709-733.

Visser, W. (2008). Corporate social responsibility in developing countries. In A. Crane, A. McWilliams, D. Matten, J. Moon, \& D. Siegel (Eds.), The Oxford handbook of corporate social responsibility (pp. 473-479). Oxford: Oxford University Press.

Viswanathan, M., \& Rosa, J. A. (2010). Understanding subsistence marketplaces: Toward sustainable consumption and commerce for a better world. Journal of Business Research, 63(6), 535-537.

Wang, H., Tong, L., Takeuchi, R., \& George, G. (2016). Corporate social responsibility: An overview and new research directions thematic issue on corporate social responsibility. Academy of Management Journal, 59(2), 534-544.

Wang, S. L., \& Cuervo-Cazurra, A. (2017). Overcoming human capital voids in underdeveloped countries. Global Strategy Journal, 7(1), 36-57.

Weyzig, F. (2006). Local and global dimensions of corporate social responsibility in Mexico. Journal of Corporate Citizenship, 24, 69-81.

World Bank (2013). Inclusion Matters. The foundation for shared prosperity. Washington D.C.: The World Bank Publications.

World Bank (2018). The Atlas of Sustainable Development Goals. Washington D.C.: The World Bank Publications.

Wright, C., \& Nyberg, D. (2017). An inconvenient truth: How organizations translate climate change into business as usual. Academy of Management Journal, 60(5), 1633-1661.

Yin, J., \& Jamali, D. (2016). Strategic corporate social responsibility of multinational companies subsidiaries in emerging markets: Evidence from China. Long Range Planning, 49(5), 541-558.

Yin, J., \& Zhang, Y. (2012). Institutional dynamics and corporate social responsibility (CSR) in an emerging country context: Evidence from China. Journal of Business Ethics, 111(2), 301-316. 
Yin, R. K. (2003). Case study research: Design and methods. London: Sage Publications.

Zhao, M., Tan, J., \& Park, S. H. (2014). From voids to sophistication: Institutional environment and MNC CSR crisis in emerging markets. Journal of Business Ethics, 122(4), 655-674.

Zheng, J., \& Wang, L. (2014). Institutions and development: The case of China in comparative perspectives. Emerging Markets Finance and Trade, 50(6), 4-20.

How to cite this article: Forcadell FJ, Aracil E. Can multinational companies foster institutional change and sustainable development in emerging countries? A case study. Bus Strat Dev. 2019;1-15. https://doi.org/10.1002/bsd2.45https://doi. org/10.1002/bsd2.45

\section{APPENDIX A}

\section{INTERVIEWER'S GUIDE}

A. Corporate social responsibility aimed at institutional necessities motivations

Theoretical rationale: Analyse whether firms' corporate social responsibility (CSR) obeys to normative or ethical motivations and whether this strategy is unique for the overall organization or designed ad hoc to address local institutional needs.

Questions: Would you define your CSR strategy as transnational or is it built ad hoc to the host country's specific needs? Do you think that your company encounters specific barriers when trying to adapt its CSR strategy to the destination country reality? Are these barriers or difficulties related to (a) external conditions (i.e., difficulty in assessing the specific social or institutional conditions in the host country); (b) internal forces, such as lack of resources or need to deploy the strategies designed in the headquarters to every country where the company is present?

B. Operational aspects

Theoretical rationale: Find out the specific mechanisms that allow companies deliver institutional change, that is, institutional entrepreneurship, multistakeholder initiatives, interconnection of different institutional dimensions, and subsidiary entrepreneurship.

Questions: Would you say that subsidiaries hold a certain degree of autonomy to design and implement local CSR strategies? In destination countries, does the company openly seek to collaborate with other companies or government to improve social conditions? Are there specific barriers-internal and/or external-that prevent reaching these agreements? Are the sustainable development goals shared by the organization? Would you focus on specific goals or would you try to achieve a constellation of goals by differentiating direct and indirect impacts?

C. Analytical aspects

Theoretical rationale: To understand how the company perceives or quantifies the effect of its CSR strategies on sustainable development and the efforts made concerning data collection and analysis of the different institutional dimensions and their co-evolution.

Questions: How does your company measure the effect of socially responsible and/or sustainable strategies? Is there a particular set of indicators that you follow? Are these built in-house or by an external provider? Are these indicators shared with employees? Would you set internal and/or external goals related to those indicators? How would your internal indicators of sustainability, if existent, relate to the sustainable development goal? 